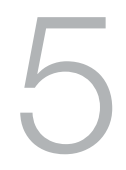

\title{
The Extraordinary Values of Ordinary Objects: String Bags and Pandanus Mats as Korafe Women's Wealth?
}

\section{Elisabetta Gnecchi-Ruscone}

\section{Introduction}

Korafe women, like the neighbouring Maisin, Miniafe and Ubir women, have long been recognised in regional and national contexts as coming from the Cape Nelson/Collingwood Bay area of Papua New Guinea because of their distinctive facial tattoos and barkcloth. Beyond this 'ethnic' or regional identity, these items of body adornment are also constitutive of the gender identity of the village women who wear and produce them (Barker 2008; Hermkens 2013). Like many other aspects of villagers' lives, the practices and significance linked to tattoos and barkcloths have been transformed in the years since the incorporation of villagers into the colonial national and global worlds (Gnecchi-Ruscone and Hasselberg 2012). While tattoos have mostly been relinquished in recent years, barkcloths have retained their importance as women's valuables and as markers of local identity, particularly in the context of struggles for self-determination by Collingwood Bay people in the face of unscrupulous deforestation plans (Barker 2008). Anna-Karina Hermkens (2013) has carefully documented the performative aspects of barkcloth 
production, use and exchange as gift and as commodity by Maisin women; drawing out the links between the objects' life histories and the material side of people's identities (see also Hermkens this volume).

I am interested in exploring two objects that may be less distinctive, but that are used daily by women in Collingwood Bay-namely string bags and mats. Pierre Lemmonier rightly calls us to consider the involvement of mundane objects in different aspects of a group's social life, and the nonverbal communication they participate in as 'revealed when we regard them as things to make, manipulate and act upon, and not-or not only_something to look at, decipher, exchange, or discuss' (2012: 134). I want to explore the ways in which string bags and mats, 'render tangible or actualise in a performative way important aspects of social organisation, culture, systems of thought, or actions' (14).

Following Hermkens' example, I will consider these two items of women's wealth to have different biographies pertaining to different realms (technical, ritual and social). 'Within these biographies each object is expected to follow a desirable ... life path' (Hermkens 2013: 331). These paths intersect with different fields of action such as marriage, exchange, identity and brother-sister relationships. Of particular relevance here are the concepts of 'affordances' and 'mapping' as applied to Melanesian contexts by Graeme Were, who argues for a locally shared logic that 'emphasizes a focus on material thinking, not just on the properties of materials, but also on how these properties-through transformationconnect to the social world' (2013: 585). Simply stated, affordances are the possibilities that people, the makers of things, can perceive in the different materials available in their environment-guiding their choice of material, and influencing the structure and form of the final object. Conversely, mapping is a 'logical property of affordance', which allows us to consider the intersubjectively shared logic by which the transformation of material through the intentions, choices and design of men or women connects its intrinsic physical properties to the expression of social realities.

The technical life of objects involves the process of transforming raw materials into valuable items, which occurs through women's specific intentional actions. These actions entail processes of how the required know-how and skills are obtained, as well as the changes in technology that have been incorporated by women in the manufacturing of string bags and mats. Ludovic Coupaye affirms that the values, qualities and properties of artefacts are not given characteristics of the objects, but 
result from technical processes of production; they are 'capacities intentionally placed within, ingrained, embodied or materialised in the artefact' (2013: 92). Tim Ingold's reflection that things are not finished at the end of their production process but are 'carried on in their use' (2013: 85-100) suggests that such properties flow into their ensuing life paths.

Applying the concepts of affordance and mapping to the study of Nalik pandanus mats, Were is able to associate the use of two distinct types of pandanus leaves to produce different types of mats expressing different social relations. Amotmot pandanus leaves are used to make stitched mats; concomitant with their protective function during life-cycle ritual is their association to more traditional, short-term local relationships. Awoiwo i pandanus leaves, however, are used in the production of more durable plaited mats, of imported design, and they are used in more mundane situations and associated with a wider network of individualised relations (Were 2013: 596), thus confirming Lemmonier's (2012) claims concerning the performative properties of material goods in expressing social relations.

In the following pages, I will follow the biographies of string bags and mats made by Korafe women, showing their life histories and entanglements with diverse fields of action and thought. Like the Nalik, Korafe use different pandanus leaves to produce stitched and plaited mats and, like them, they privilege the more local stitched mats in ceremonial occasions. String bags can also be made with different materials: natural fibre, now reserved for special string bags that signal the wearer's commitment to traditional values; and the more practical, versatile and durable artificial string, used for more ordinary string bags. However, objects too have a life history. In life-cycle rituals, things that are commonly used in mundane situations follow a ritual path. As such, their social life comprises the transactional dimension of valuables and how women use them in life-cycle exchanges to establish and maintain relations. Developing Arjun Appadurai's (1986) argument that things move between social contexts, both Maureen MacKenzie (1991) and Hermkens (2013) have demonstrated that objects made by women acquire different meanings and values in the course of their lives. Following on their insights, I will show that string bags and pandanus mats are valuable in that they are indispensable items of daily work and life, embodying the labour of their makers, and that they acquire ritual value when they are used in life-cycle ceremonies. In fact, these items objectify particular women's work and intentions in creating and sustaining relations through informal exchanges. 
The question that remains open, then, relates to the introduction of string bags and pandanus mats into formal exchange networks between clans. Annette Weiner launched the debate on women's wealth with her groundbreaking ethnography Women of Value, Men of Renown: New Perspectives in Trobriand Exchange (1976). She described sagali exchanges in which Trobriand women ceremonially exchange banana leaf bundles and skirts as 'women's wealth'. Here, women compete to gain power and prestige for themselves and their matrilinear subclans (dala) within a context that is separate from, yet interdependent with men's exchanges. Weiner concludes that the sagali exchanges are pivotal in the reproduction of each dala and of Trobriand society as a whole (see also Lepani, and MacCarthy this volume). My question, therefore, is whether string bags and mats, when given by women in the context of ceremonial exchanges, can be said to become women's wealth.

\section{Making string bags}

There is a constant need for string bags (áti), and women of all ages are continuously making new ones. Girls and women who are not busy with other tasks, such as gardening or cooking, are often looping string bags. Deft women can also continue looping while walking. Often young girls sit next to more expert women-their sisters, mothers and grandmothers-in order to draw on their skills and knowledge when they run into difficulty, or when they start a new kind of stitch. Making a string bag is considered to be a very time-consuming task, it can take weeks, but then a good quality át $i$ can withstand several years of heavyduty, daily use.

The majority of string bags are now made from synthetic string. Both women and girls enjoy experimenting with the possibilities offered by colourful store-bought strings. The front side of the string bag-the one that is seen when it is carried hanging over one's back-is decorated by alternating sections resulting from the use of different elaborate stitches within and between rows of loops. The resulting textured appearance, combined with the alternating colours, allows women to create their own distinctive patterns, which personalises their string bags. The back part is made using plain stitches (binóno) only; whatever colour thread was being used at the end of the row at the front runs into the back part until it is used up, thus the pattern of colours on the rear is casual. 
Some women elect certain colours and patterns as their preferred designs, and become associated with them. For example, Jessette Ikirima, a senior woman from Goodenough village, uses red, black and white strings; she says that the particular combination of colours and stitches that she employs is her own distinctive personal mark. Both times I left the village after a period of fieldwork (in 1988 and then 2014), she retrieved a string bag stored inside her house to give to me as a farewell gift. Although 27 years had passed between the two occasions, the bags she gave me were virtually identical (Figure 23).

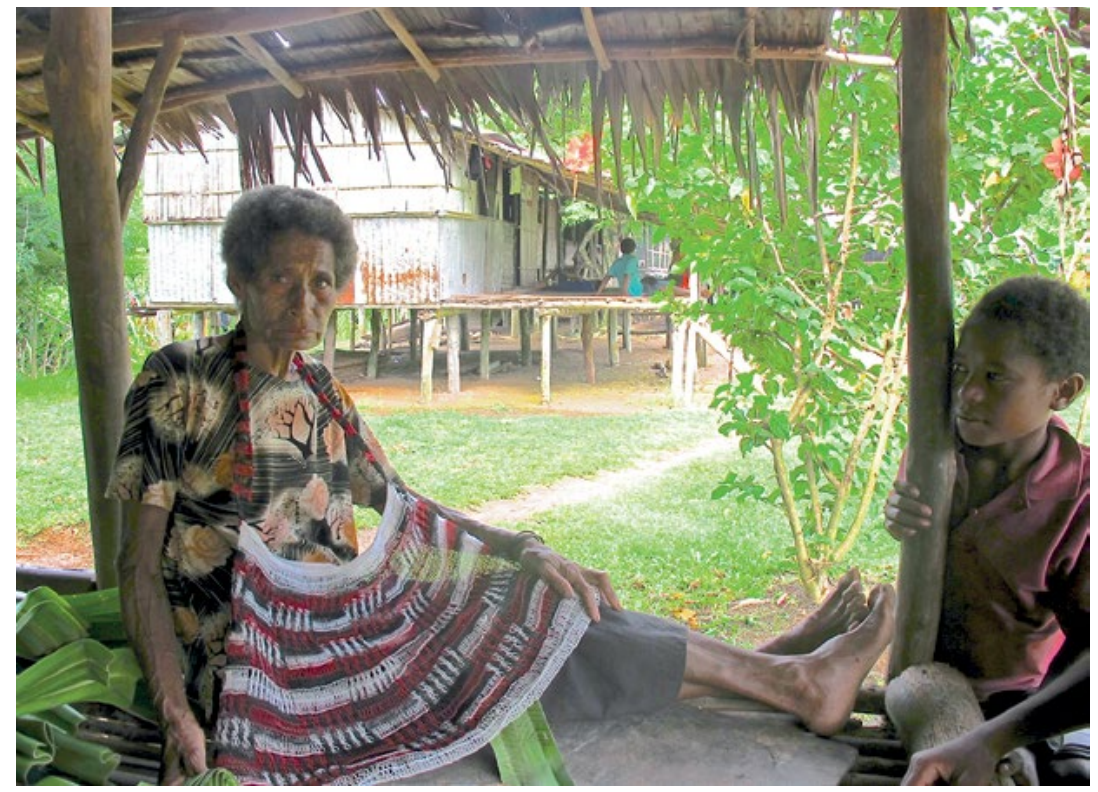

Figure 23. Jessette presents a newly unfurled string bag

Source. Photographed by Elisabetta Gnecchi-Ruscone, 19 January 2014 and used with Jessette's permission ${ }^{1}$

Some looping styles 'belong' to specific clans. Women from the Jávosa clan, for example, make the base of the string bag using a stitch, called kóke, resembling the footprints of kóke bowerbirds (Farr et al. 2008: 313). Other types of stitch are peculiar to different parts of the bag: closer-knit loops (sokifa) are used to fashion the base; others are used to finish the bag, forming and strengthening its mouth (bondiba and rivvi, respectively); yet other stitches make up the strap (tino) by which it is carried.

1 Permission to publish the photographs used in this paper, as well as the names of the people in them, was given on 25 August 2015. 
Before nylon string became available, string bags were made with fibres from the inner bark of the siria tree (Gnetum gnemon [Gnetaceae]). ${ }^{2}$ The women would strip the bark off the plant, remove the outer layer and beat the softer fibres before leaving them in the sun to dry. They would then tear the fibres (vijari) and use the palm of their open hands to make a three-ply string kàina by rolling the fibre up and down their calf (avàri). The string could be left undyed (ésa), be steeped in black dye produced by burning the resin from the baningu tree, or dyed red by boiling it with the bark of a type of mangrove (fofóra). Today, women use a combination of bush and store-bought dyes.

Because of the considerable extra work involved, women only occasionally make string bags with kàina: usually to give to someone or for sale to tourists. Jessette had been asked by her classificatory brother to make him a personal string bag using bush string and the customary combination of white, black and red colours. This was a long-term project, involving many hours of work, which she fitted into her busy routine over a period of several weeks when she had the time to spare. Recognising this, her brother had harvested the fibres himself, saving her a trip into the bush.

\section{Using string bags}

Once she has completed a string bag, a woman turns it inside out and rolls it up for storing. Ati jojegári refers to the action of unfurling it and turning it back to the right side, when it is to be used for the first time. Knowing how to store and preserve a string bag, and the gesture involved in giving it to someone to use is as important as knowing how to make it.

String bags are essentially containers for carrying useful, valuable and precious things. Women always carry them hanging against their backs, suspended by the strap from their foreheads. When the load is particularly heavy, women use a padding of leaves or cloth to protect their shoulders. Similarly, a smaller padding may be placed between the strap and the woman's forehead to prevent it from biting into her skin. There are several types of string bags of varying sizes for carrying different kinds of things. The larger ones (áti yabámara) are specifically intended for carrying mats, pillows, blankets, clothes or other voluminous but not too heavy items needed by the woman and her family on trading trips to other villages.

2 For scientific names of natural species I refer to Farr et al. (2008). 
Large amounts of tubers and other produce are carried in the coarser gámo ati. These string bags stretch to accommodate heavy loads, to the point that a woman might ask someone to help her haul it up into position. Once in place, she is able to walk long distances carrying produce to her village, the market or to the venue of a feast.

Mothers have a further string bag (tatáu), in which they carry their lastborn baby. These string bags are beautifully manufactured using different coloured strings. The baby lies on a pillow within the womb-like netbag, it can be shaded from strong sunlight with a piece of cloth draped over the mouth of the bag. The tatáu allows the mother to work while cradling the child, or to hang it in a nearby shady spot. A fretful infant can be pacified by swinging the string bag backwards and forwards or by walking with a bouncing step (boinboinghari). Usually, however, a baby is placed inside the string bag once it has fallen asleep, and when it awakes it is peeled out of the tatáu to be changed or fed. Although fathers participate in many aspects of their children's rearing - they play, clean and even rock them to sleep by swinging a hanging tatáu-I have never seen a man carrying one on his back as a woman would.

Finally, every woman owns a smaller string bag, called túmo áti. This is a woman's personal string bag in which she carries tobacco, betel, money and her small knife. Men also use small personal string bags. Unlike women, they sling the strap over their shoulder. A man's string bag is called jávo, the same term used for 'personal name', and is closely linked to its owner's identity. A man's jávo contains his most personal and precious possessions, such as his personal cutlery, a mirror and comb, his tobacco, as well as betel, pepper and a lime pot. These items are associated with a man's powers and they are also vulnerable to sorcery attacks, therefore it is considered extremely bad mannered and dangerous to touch another man's string bag. A powerful man's jávo is also out of bounds to his wife and children, who will not touch it unless expressly instructed by the owner. At his death, a man's widow packs his jávo with all those items that he used to carry with him on a journey. This is buried with him to accompany him on his last journey (Gnecchi-Ruscone 2007).

Significantly, a man's jávo is made by a female relative-generally his mother, sister or wife. The owner's clan emblems that are part of the bag's stitching pattern are made by the women, but other emblems such as shells or feathers are applied subsequently by the jávo owner himself. MacKenzie (1991: 157-60) has argued that when Telefol women give 
their male relatives string bags that they have looped, and to which men apply feathers, the resulting feathered bilums are the product of multiple authorship (Strathern 1988) and a metonym of the relation between women and men, giver and receiver. Hermkens too, commenting on Maisin women's production of barkcloth painted with clan emblems, makes the point that while women are reenacting notions of gender and gender relations, they are also responsible for the creation, reproduction and transmission of an important kind of their patrilineal clans' emblems and, as such, clan identity $(2013: 27,86,116,139,145-46)$.

Beyond their utilitarian function, then, string bags are also articles of personal adornment. In the everyday context, string bags are perhaps the most recognisably 'traditional' element of contemporary dress, regardless of the creative incorporation of new materials, colours and looping techniques. Indeed, this very flexibility permits wearers to express diverse aspects of their identity, such as gender, age, marital status, clan identity and aesthetic taste. Carrying a string bag made with bush material displaying the conventional red, white and black pattern is a statement of ethnic identity, and adherence to customary values. This choice is often made by senior men, who also add clan emblems to their jávo, communicating a further layer of identity. In contrast, younger men are more likely to adopt western-style bags, expressing adherence to modern or cosmopolitan values. Attachment to traditional values is also implied by women who make áti with bush string, whether they make them for themselves, to give to men or for the tourist market, where the traditional aesthetic is translated into monetary value.

\section{Exchanging string bags}

Women often make string bags to give in different types of transactions, which are invested with different meanings and significance: little girls were encouraged to make miniature át $i$ to give me to take home to Italy, but sisters and cousins, grandmothers and granddaughters, and girlfriends all regularly made string bags to give each other informally; the recipient discussing the colours and patterns with the maker. The significance of these informal exchanges is that of consolidating the kind of habitual and expected reciprocity among friends and kin sharing close relations. Similarly, the gifts of jávo made by women for the men to whom they are related - their brothers, husbands and sons-are expressions of love and attachment, and establish or confirm long-term relationships. At the same 
time, though, the jávo given by a woman to a man is a reminder of the cross-clan relationships for which women are responsible and which, in their multiple roles as wives/mothers and daughters/sisters, they mediate. The maker of this string bag, from the point of view of the recipient, is in every case the representative of the 'other' clan to which she belongs.

There are several ceremonial occasions on which women make formal gifts of string bags. Since a woman is expected to participate in the gifts made by her husband's clan as well as that of her brothers', a farsighted woman will have a few spare string bags (as well as other items such as clay pots, ${ }^{3}$ mats and barkcloths) to contribute to exchanges occurring at first-born child 'decoration' (vujári), marriage exchanges (Figure 24) and the ceremonies in which a widow is released from mourning obligations and decorated with new clothes and a new string bag (also called vujári, see Gnecchi-Ruscone 2007).

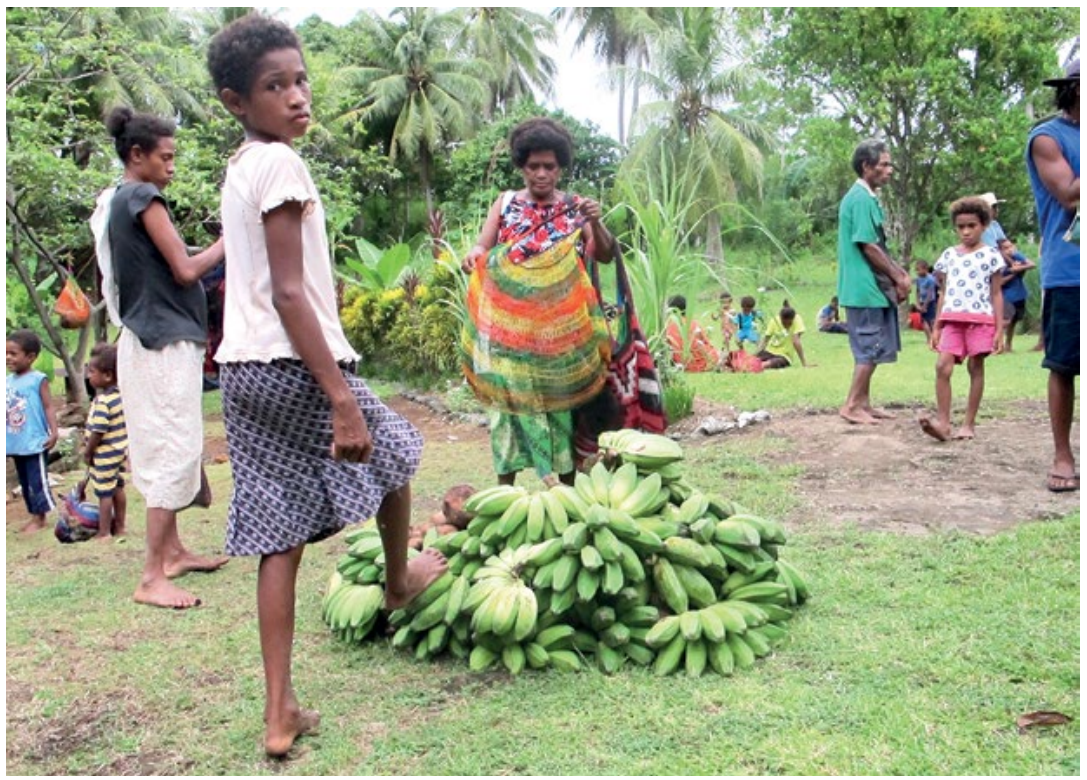

Figure 24. Women belonging to the groom's support group retrieving their string bags

Source. Photographed by Elisabetta Gnecchi-Ruscone, 15 January 2014

3 Clay pots are also made by women. They are now used mainly on festive occasions, exchanged at marriage and during vujári. They are not considered in this paper because they are not produced by Korafe women, but obtained by exchange with Ubir women from the Wanigela area (see Bonshek this volume). 
While some string bags are gifts in their own right, others are filled with cloth or barkcloth and then given, acting as both vessel and gift. These are called áti ghayáfa, the same term being used for wealth exchange goods. On other ceremonial occasions, however, string bags are used merely as carriers. Once emptied, the áti are retrieved by their owners (Figure 24).

Other string bags are made and stored as future gifts. For example, mothers of adolescent boys set aside atti they will one day give to their sons' brides. These are important gifts as they convey several messages. A predominant association is that with adult womanhood and motherhood (see also MacKenzie 1991: 130). This gift, like other acts confirming the newcomer's welcome by the women with whom she will henceforth share most of her daily tasks, is expected. The act of giving is performed by the gesture of áti jojegári, in which the giver unfurls and opens up the string bag, ready for use. Both gift and gesture will be remembered, or reproachfully commented upon if not performed by the new wife.

So, string bags are versatile objects; they are made by women with different objectives and for diverse functions, which in some cases influence the choice of materials used. Nylon thread, being easily obtainable, durable, colourful and saving the woman many hours of work is preferred in most cases in the production of the utilitarian kind of string bags used to carry garden produce and to cradle infants. The importance of women's work in the production of garden food and the reproduction of children is reflected in the ceremonial giving of string bags in the context of life-cycle ceremonies, as well as the mother-in-law's gift to the new bride. A world of values is embodied in these objects throughout their technical, social and ritual lives. First of all, they represent women's patient work, as tatáu they affirm the values of maternity, as jávo they perform personal and clan identity, as gámo áti they embody the value of women as providers of abundance. When given, they express the value of the relations involved. Next, I will follow the life of another utilitarian item of women's wealththe pandanus mat.

\section{Making pandanus mats}

Korafe women make two types of mats. Gháito, considered as the truly autochthonous mat, is made by sewing together a double layer of wide strips of gháito leaves from the mónga (Pandanus pistillaris) plant, which is a bush variety with wide leaves. Savásava mats are made 
by weaving together narrower strips of leaves of the jégha (Pandanus tectorius, Pandanus Sanderi) or saságha (Pandanus englerianus, Pandanus kruaelianus) varieties. The savásava mat is as common as the gháito in Korafe households, but it is regarded as a cultural import from Milne Bay. This resonates with the use of two similar types of mats among the Nalik of New Ireland: traditional stitched mats that are attributed with protective properties and used in ritual; and the more common plaited mats, which are used for sitting and sleeping, and believed to have been introduced by Polynesian missionaries (Were 2013: 594).

Mats are made by most adult women, but it is not an activity in which women engage every day. A mat may be made in a few days of concentrated work, particularly in the dry season. While women tend to stockpile string bags for future exchanges, mats are made as required. A woman wishing to make a mat begins by going to search for pandanus plants, which usually grow spontaneously in the bush. Tall plants may be cut down in order to harvest the leaves; however, it is preferable to take the leaves from shorter plants, taking care not to damage the growth tip, so that in time new leaves may be harvested.

Pandanus leaves are tough and lined along the edges and midrib by stiff and sharp thorns; women usually remove the thorns before tying the leaves into bundles and carrying them home. Finding, harvesting and carrying the leaves home is considered to be the most physically demanding part of the task of making mats. Women may enlist helpers from among their immediate family. Once a woman has gathered sufficient leaves, she begins treating them; turning the fresh, bright green, tough leaves with their longitudinal ribbing into flat, soft, smooth, pliable strips of material to be woven or sewn together. The work of transformation involves the whole woman's body adopting postures and making gestures that are mutually constitutive: defining the female body while giving shape and form to the object (cf. Hermkens 2013: $74 \mathrm{ff}$. on similar processes involved in Maisin women's production of barkcloth).

Independently of the type of mat, the same processes are required to prepare the leaves. Each leaf has to be laid out in the sun for a couple of hours to soften, then brought back into the shade of the verandah. Here the woman places two leaves at a time on top of each other, with the leaves' central fold upwards, she presses down with the heel of her hand along the length of the softened leaves to flatten them, obtaining two smooth strips. These she rolls tightly, if necessary she sits on them using her weight 
to flatten them further. Then she vigorously scrapes each leaf with the sandpaper-like bikororo (ficus wassa) leaves to render its surface smooth and pleasing to the touch and facilitate the drying process (Figure 25).

If the woman wishes to make a plaited mat, the leaves are sliced into narrow strips. Women making gháito can decide to scratch patterns onto about half their strips, although frequently they are left undecorated. The design can be anything that pleases the woman, usually a simple geometric motif repeated along the length of each strip of pandanus, but different on each strip. Typically, the gháito will then be made of alternating plain and decorated strips. Next, the woman loosely rolls the leaves individually and places them in the sun to dry further, making the patterns stand out. When the leaves begin to dry, women unroll them and roll them up in the opposite direction, so that the strips lie flat without curling. Finally, the woman can sit down to sew or plait her mat. Some women embellish their savásava by dyeing some strips blue or purple by boiling them in a pot of water to which is added store-purchased dye (Figure 26).

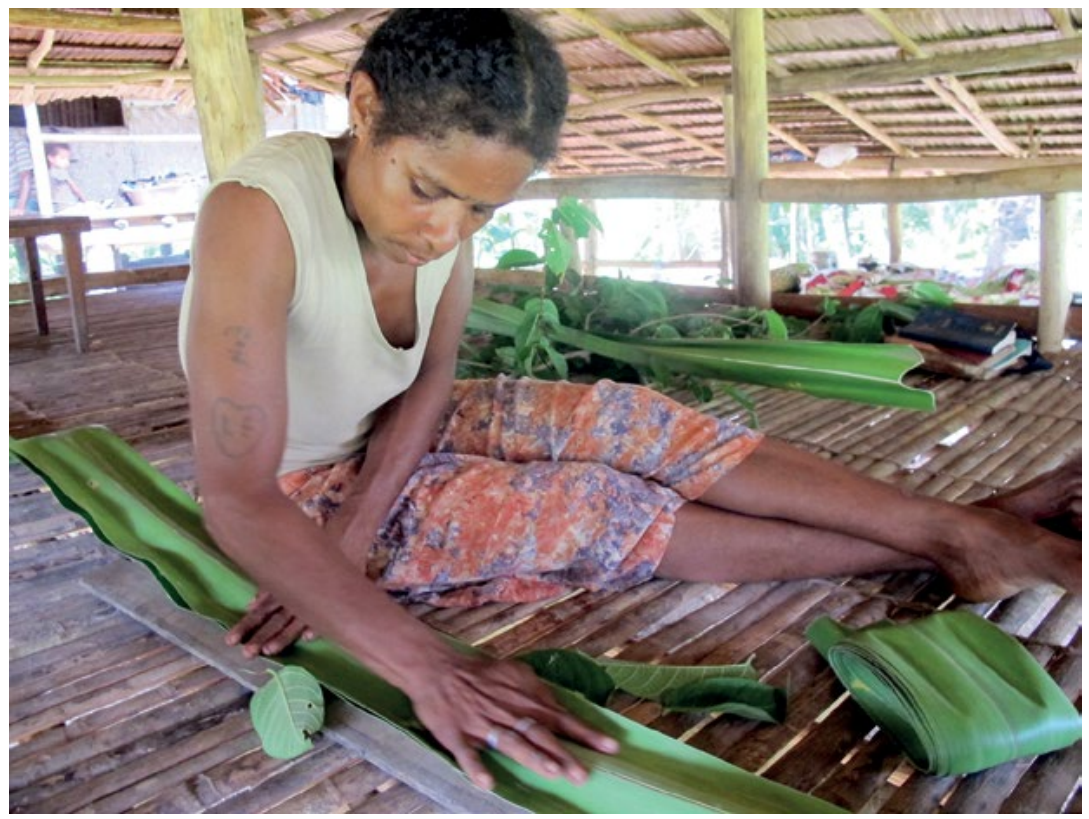

Figure 25. Ethel flattening and scraping the pandanus leaf with a bikororo leaf

Source. Photographed by Elisabetta Gnecchi-Ruscone, 17 January 2014, and used with Ethel's permission 
5. THE EXTRAORDINARY VALUES OF ORDINARY OBJECTS

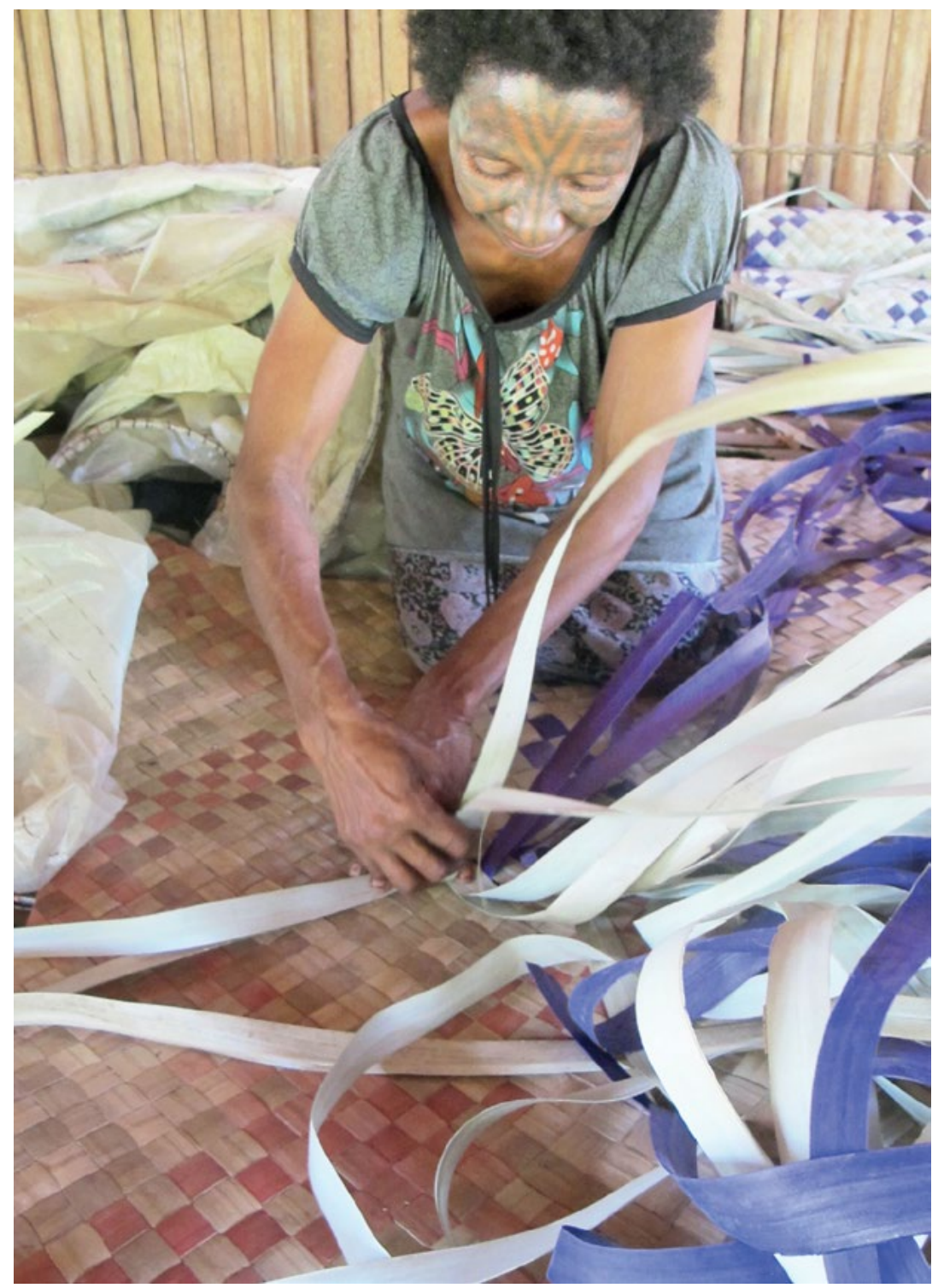

Figure 26. Elma making a savasava

Source. Photographed by Elisabetta Gnecchi-Ruscone, 16 January 2014, and used with Elma's permission 
Although younger women told me that they favoured making savásava because plaiting was easier than stitching, gháito makers said that sewing was the easier part of the work. Given this different evaluation, I asked the women which part of the work they preferred. They explained that since they needed mats, they knew that they had to go to the bush to get pandanus leaves, remove thorns, scrape and dry the leaves in the sun and then sew or plait the mat: all parts of the work were necessary and they had no preference. Their work was not considered in terms of pleasure, but as the outcome of their intentions, an expression of agency. As Richard Eves in his article on dance objects argues, 'agency should be seen in terms of practice, as centrally concerned with the realisation of projects through bodily action and movement which connect people in their intersubjective world' (2009: 251). Women undertake the work of making mats with specific intentions in mind, whether it is to use it in their own home, give it to a friend, contribute it to a formal exchange or use it in ceremony. This motivates their work in all the stages of production.

In order to sew the pandanus strips to make a gháito, a woman must procure songa bark and transform it by cutting, stripping, peeling and rinsing it to obtain a hardwearing strand of binding material, the same as that used to tie together the flooring slats of local houses. She starts with four strips of pandanus leaf placed on top of each other: two strips are laid back to back so that the gómo (belly) sides of the leaves face outwards, these are sandwiched between two more strips, with their gúka (back) side outwards. She sews the layers together along one length, then folds back the two outer strips concealing the stitches inside the fold. She thus obtains two double-layered strips of pandanus with the belly side visible on both sides. She then takes two further leaves, uses them to sandwich the second strip, back side outwards, and tacks these together along the outer edge before folding back the outer strips, concealing the stitches and revealing the belly of the leaf. The process is repeated until the desired length (to accommodate a sleeping person) is obtained. The woman periodically smooths down the pandanus with her hands, applying the whole weight of her arms and upper body to the task (Figure 27). After paring down any longer strips to make straight edges, she folds the gháito in two longitudinally, pressing down strongly to make a permanent crease. 


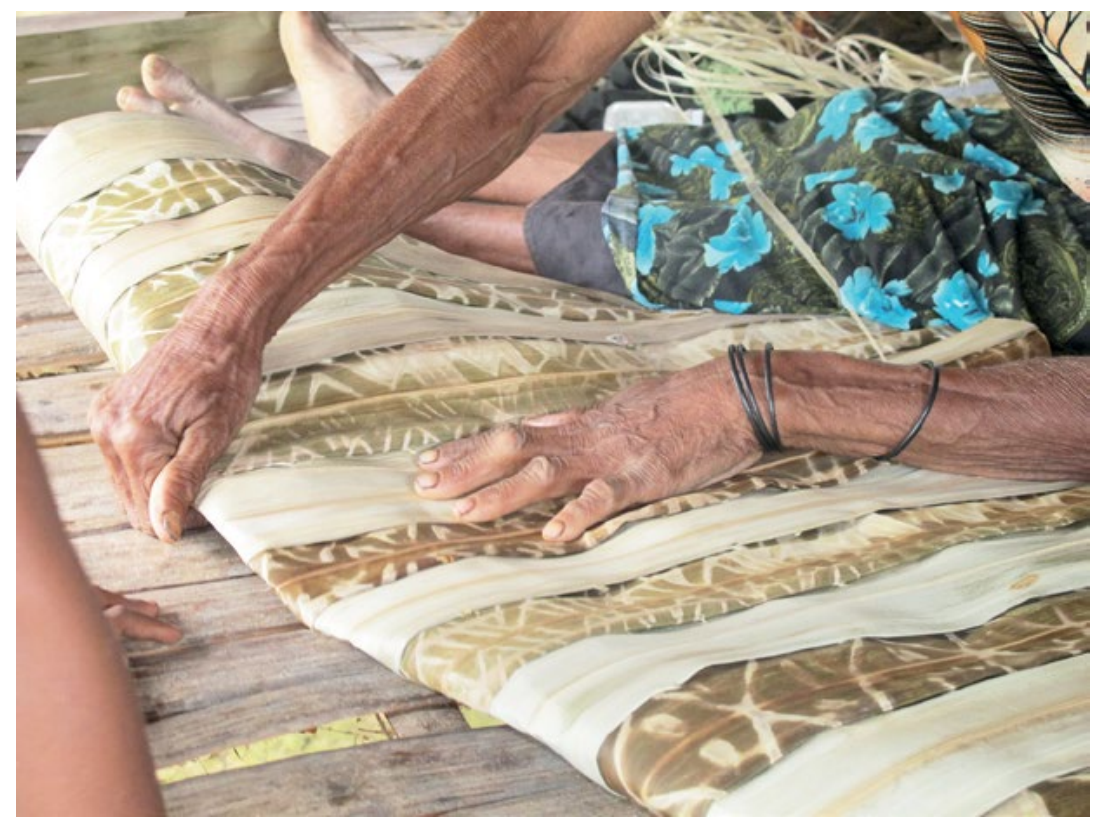

Figure 27. Jessette folds the mat

Source. Photographed by Elisabetta Gnecchi-Ruscone, 25 January 2014, and used with Jessette's permission

The last stage in manufacturing a stitched mat involves sewing three longitudinal rows of stitches; the only visible stitching on a gháito, these are regarded as essential for its structural durability. First, a woman sews the two rows of stitches bordering the long sides of the mat (no sewing is required along the short sides). A couple of strands of songa fibre, the same length as the mat, are knotted together making small tassels at both ends. The strands are secured, about one centimetre in from the mat's edge, with small, tight-knit stitches crossing over them. The stitches (diti, lit. 'eyes') are visible on both sides of the mat, but the strands of songa are applied on one side only, visible when the mat is folded but on the underside when it is laid out. Finally, the woman stitches along the longitudinal crease created by folding the mat in half (Figure 28). This time she carefully sews only through the top layer, as these stitches (gonia, lit. 'buttocks') are to be visible only on the side of the mat on which people sit, and remain inside when the mat is folded. 


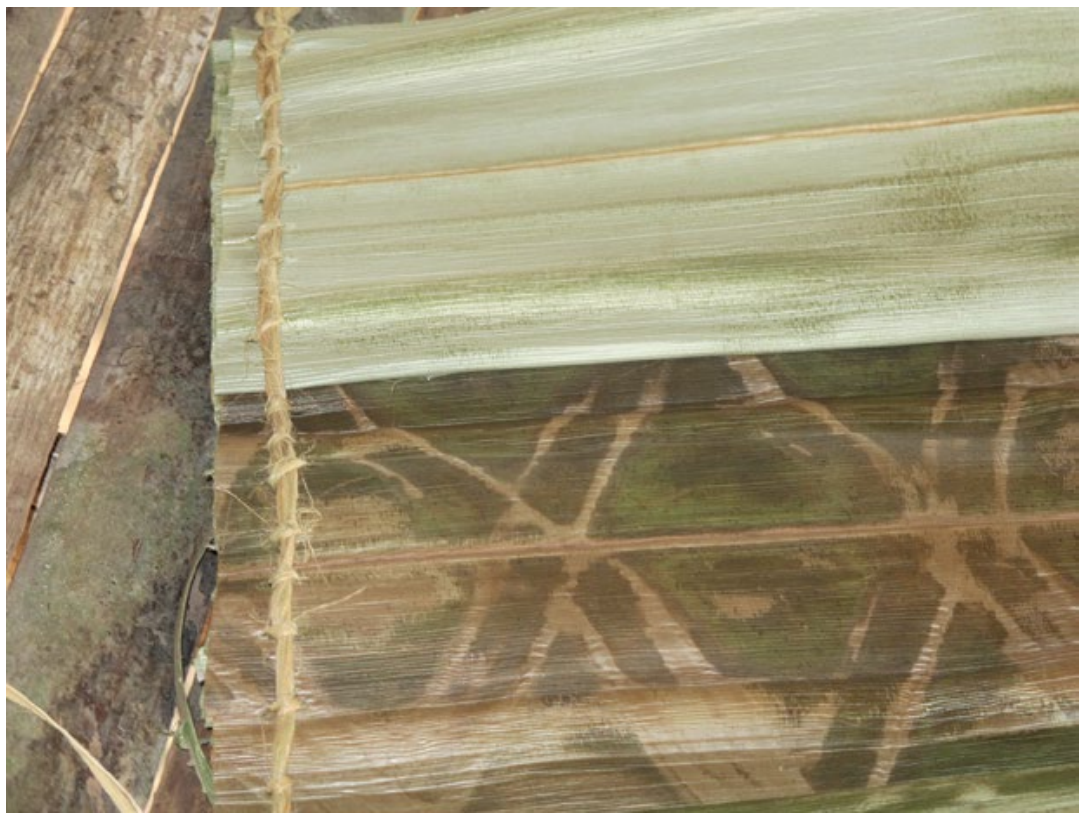

Figure 28. Side-stitching the mat

Source. Photographed by Elisabetta Gnecchi-Ruscone, 21 January 2014

There is a very physical quality in the rapport between maker, materials and the mat in the making: on the one hand, there is a deep knowledge of the properties of the materials that 'grows out of a lifetime of intimate gestural and sensory engagement' with their craft; on the other, the 'intelligent gesture, at once technically effective and perceptually attentive' (Ingold 2013: 42, 132). The knowledge and skills needed to make mats are not acquired through formal instruction but through observing and copying older women. The actions involved are just some of the many tasks that fill a woman's daily life. She fits them into her daily routine, and may enlist the help of any willing girl-in the process, she creates the conditions for girls to experience the actions involved and passes on technical knowledge. Girls accompany their mothers into the bush, observe them harvesting leaves and help out in the casual manner arising from sharing daily life in the village. They may be asked to go and pick some leaves for scraping the pandanus, or to roll the strips and help by shifting them from sun to shade. Equally, they might choose to join in the fun when their grandmother is scratching patterns on the leaves, or their aunt is steeping narrow strips of pandanus in a pot filled with purple dye. Thus, informally, girls acquire skills that are considered part of every adult women's repertoire (Young Leslie 2007: 13) (Figure 29). 


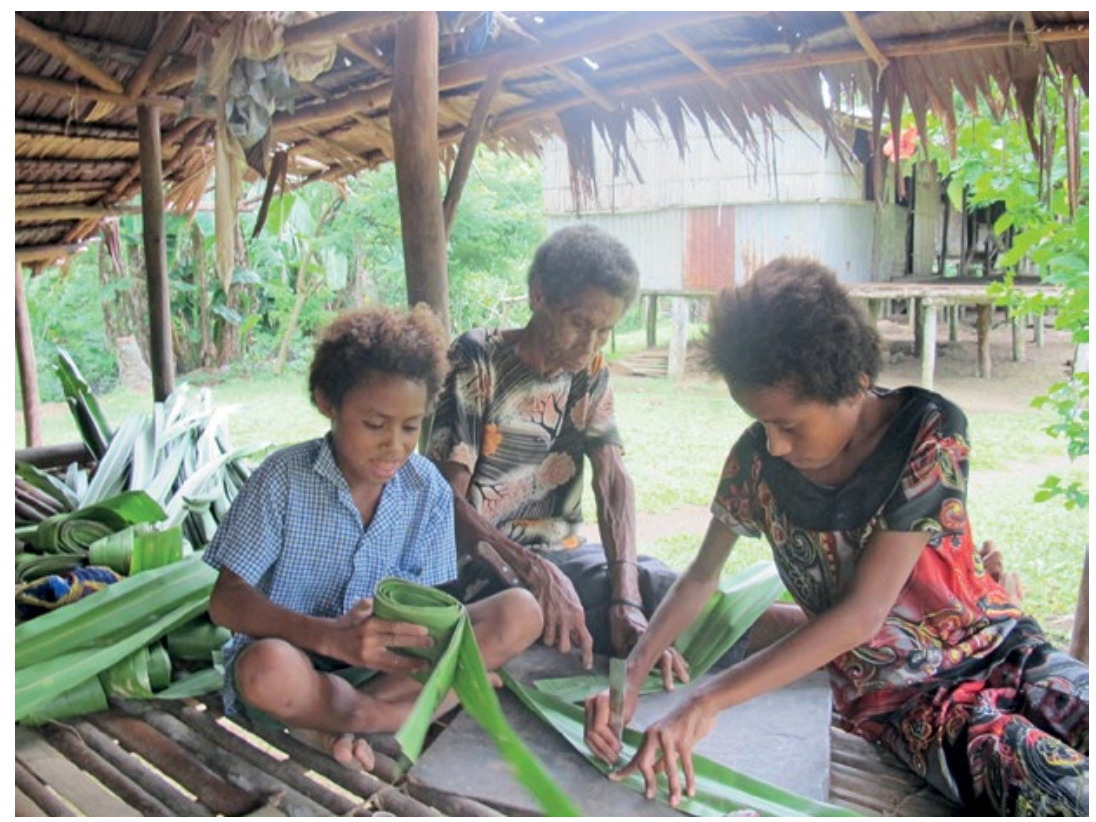

Figure 29. Jessette and granddaughters scratching patterns into pandanus leaves

Source. Photographed by Elisabetta Gnecchi-Ruscone, 19 January 2014

In short, it is through a woman's actions, through postures and gestures that are typical of women only, that bush material is transformed into household objects, used daily by her family for sleeping, eating and socialising. The intimate, physical actions of the woman's body upon bush pandanus leaves produce an artefact that may be described as creating domesticity. As expressed by two women from Goodenough village: 'Mats are important because they are part of life in a house, everyone in the family needs a mat to sleep on' (Elma, 18 January 2014); and 'If you have a house, you must have mats for your family to sleep on, and for guests to sit on' (Lila, 15 January 2014).

\section{Using mats}

Women thus domesticate bush pandanus leaves to make artefacts that create delimited spaces separate from the surrounding clutter of everyday activities, defining safe spaces where family members sleep and eat. Graeme Were comments on the protective properties attributed to pandanus mats, referring to the well-documented protective function of woven wrappings 
in Oceania in general (2013: 590-91). By observing the ways in which Korafe women use their mats, I wish to show that the protective function of ghaito is not limited to the rare circumstances in which they are used as covering.

Clever women, as well as knowing how to make mats, also know how to use and care for them to ensure they last a long time. While older mats are left lying on the veranda, new ones are preserved from soiling and wear by storing them in the beams of the roof when not in use. A savásava mat is rolled up, while a ghaito is folded according to a specific sequence similar to folding a map (gaghári). Women accompany the actions of unfurling and laying (javuregári and durári) a mat on the ground with a smoothing gesture of their open hands, to flatten it and brush away particles of dirt. A gesture with which we are familiar from having observed the women making the mat: one instance of the flowing of things between production and use (Ingold 2013), but also of the way in which the gestures that make a thing also define its maker (Hermkens 2013).

At the most mundane level, mats are used for sitting, eating and sleeping on. Mothers labour on mats, and babies are born on them. Married couples share the same mat, and the association between mats and conjugal life is remembered in mourning songs and laments (GnecchiRuscone 2007). While Jessette was showing me how to fold a ghàito, she was telling me that different sizes may be made: smaller for children, larger for married couples, and so on. Her husband, who was listening from the rear verandah reminded her that in pre-Christian days a polygamous man and his two wives would share a wider mat, the husband sleeping in between the two women. Jessette then explained that in this case the mat would have four rows of vertical stitching, delimiting each sleeper's space on the mat, which was accordingly folded vertically in three parts, instead of two. She added that each woman would cook for her husband, and that he would make sure to eat from each of his wives' pots, if he did not want to hurt the women's feelings and cause arguments. The connection between mats, sleeping, eating and reciprocal conjugal duties is manifest.

In all cases, the mat defines a space separate from its surroundings where people may safely perform acts that potentially make them vulnerable: eating, sleeping and giving birth. This safe space is transportable, and mats may also be carried when travelling, to create a domestic space for the family away from home. They may also be used to build makeshift shelters on canoe platforms or on the ground. 
When a visitor climbs the steps to the verandah, a great show is made of seeking out the best mat, unfolding and laying it down. These are the first gestures of hospitality and define the space reserved for guests, separate from other occupants, where they may feel comfortable and able to relax, eat and rest. At the same time, the mat limits the guest's movements; he or she will remain in the designated space without venturing inside the house. In households whose status implies that they often entertain visitors, the 'best' mat is kept in the rafters of the sitting platform ready to use. It is said that if a sorcerer should visit, the mat he sat on would be given to him to take away, as it would be too dangerous for others to use it after him. These attentions reserved for welcome guests respond to the vulnerability felt by Korafe when away from home, their fear of sorcery or contamination: a clean, freshly laid out mat provides a safe space within a potentially dangerous environment.

Gháito also figure in several ceremonial occasions, where they define a space separate from its surroundings. In the final stages of the initiation ceremony held for the eldest son or daughter of a couple, the initiand, after being decorated with the clan insignia by his or her maternal uncles, sits on a mat in the village clearing where the conclusive exchange of gifts between the parents and maternal uncles occurs. Similarly, the widow who is decorated by her deceased husband's sisters to mark the end of mourning sits on a mat while the all-night singing of ghaséga takes place (Gnecchi-Ruscone 2007). When a groom fetches his bride to take her to his village, the couple is made to sit on a mat in the centre of the village while they are addressed by the bride's brothers regarding the marriage agreement and the gifts to follow, and by the bride's mother and other senior women about the behaviour she should adopt in her new village.

On all these occasions, those sitting on the mat are in a state of transition. The gháito defines a safe space on which the transformation of the person through speech, actions and transactions occurs. In the central village clearing the most intimate of domestic objects - on which couples sleep, babies are born, family and friends partake of their meals-becomes a space where persons may safely be subjected to transformation.

Gháito are also used in burial. The body is wrapped in a sheet and placed at the bottom of a pit in the ground, a layer of sticks is laid perpendicularly over the body and covered with a new mat, protecting the body from the soil used to fill the grave. Another new gháito is placed over the mound 
of earth, and a small shelter is built above it. In another way, the mat seems to be defining and delimiting the space for the dead person's body, isolating it from dirt, even underground.

The material qualities of mats-their proportions, shape, texture, softness, visible and invisible stitching-perceptibly delimit a space apart from surrounding clutter and dirt. By the simple performative gestures of unfolding and laying a mat on the ground, women create the most intimate spaces of domestic family life, secure spaces for welcome guests to relax in, and provide safe spaces for protagonists of life-cycle ceremonies to publicly undergo social transformations. Mats also enter into formal and informal exchanges, creating and sustaining relations well beyond the domestic sphere.

\section{Exchanging mats}

A woman may produce mats to give informally to friends and relatives as part of the ongoing exchange relationships. She may decide to make a mat for a father, son or brother, especially if they are unmarried. Such gifts are sometimes solicited. Reciprocation is not immediate or equivalent, it is one of the ingredients of a continuous kinship or friendly relationship. Women also trade mats for clay pots with Ubir women from Wanigela, or sell them at the market, although this represents a slim and discontinuous source of earnings - the mats earn between 5 and 10 kina each.

Women's intentions are central to the production of such mats, which 'should be seen as embodiments of intentionality and agency made visible in the intersubjective social field' (Eves 2009: 251). For example, during January 2014, Elma was busy preparing three savásava mats to give to her teenage son when he embarked on the dinghy that would take him to Popondetta for the beginning of the school year. Elma made them to thank the family that took care of her son while he was boarding at school, and to reaffirm their mutual friendship.

Being the wet season, the process involved constant surveillance of the drying rolls. Elma enlisted the help of her husband for collecting the leaves, of her younger children for rolling and moving the strips of pandanus in and out of the sun, and of her older daughters and sister-in-law for dyeing and plaiting the mats. She thus mobilised her whole family, drawing on their work to produce mats that would reaffirm relations in a wider social field. Interestingly, Graeme Were observed among the Nalik a similar use of 
woven, as opposed to stitched, mats in an informal gift economy extending beyond New Ireland, which 'serve[d] to strengthen and consolidate social relations through the individualized productivity of female mat-makers' (2013: 595). He showed that the social and material properties of the pandanus used in woven mats allowed these to map 'an image of a wider network of individualized relations that require[d] renewal less often', while stitched mats map 'an image of localized, traditional social networks, sustained over a shorter, intense duration through its production and usage at life-cycle events' (2013: 596). ${ }^{4}$

Of a different order are the exchanges that occur for ceremonial occasions, such as marriage and initiation. Women produce a surplus of mats in anticipation of such events, as great numbers are required. Each woman will make at least 10 mats for such exchanges, and they compete among each other to demonstrate greater generosity. Great piles of gifts are built up by the women on each side of the exchange. Among these piles are mats, but also other women's artefacts like string bags, clay pots and tapa cloths. All these artefacts can be defined as valuables because they incorporate the work of women, and in virtue of their inclusion in such ceremonial gift exchanges.

Unlike the personal informal gifts described above, each woman's gifts enter into the cumulative gift made by one clan to another. Women may contribute to the gifts made by their husband's or brothers' group. From the performative point of view, there is a difference: a woman will publicly present her contribution to the gift made by her husband's clan by adding them to the pile of his clan. If she chooses to act as supporter to her brothers' clan, she will instead deliver them to its members, who will make the public gesture of adding them to their pile. Therefore, although acting as helpers to their brothers' clan is within the range of possibilities open to women, and is a frequently made choice, only their contribution to their husbands' clan appears to be prescribed. ${ }^{5}$ The gifts will be shared among the group of recipients and their supporters. A woman who gives generously can expect social recognition and a greater share of the return gifts.

4 Korafe say that both kinds of pandanus mats may be given as formal and informal gifts; however, a difference does seem to be relevant in ritual situations, in which gháito are preferred over plaited mats. 5 This distinction does not occur when the brothers' and husband's clans are the direct protagonists of the exchange: once bride price has been paid, a woman helps her husband to make gifts to give to her brothers. Women's agency in this regard applies when more distant relations are the main players in the exchange, and a woman may choose to side with her brothers. 


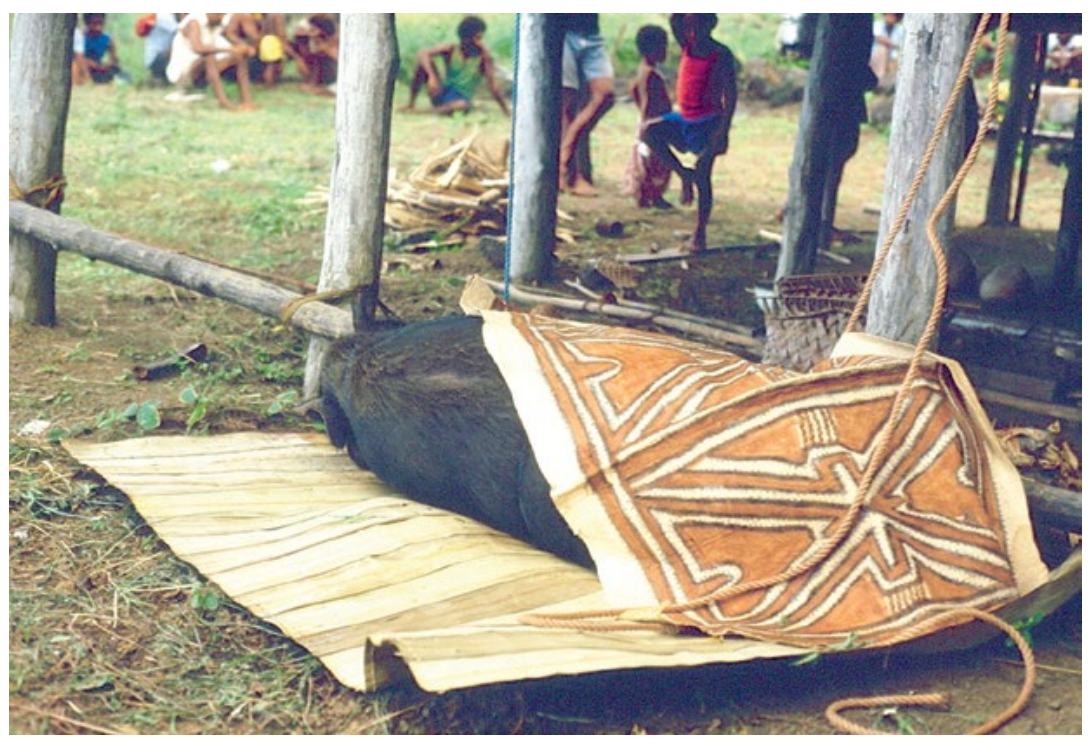

Figure 30. Pig laid on mat and covered with tapa

Source. Photographed by Elisabetta Gnecchi-Ruscone, 1988

Some of the most important exchanges are those following the satisfactory payment of bride price by the husband to his wife's brothers. The woman has effectively been separated from her brothers and cooperates with her husband in making gifts to give to her brothers for the sake of establishing and acknowledging the ties between them and her children. This series of exchanges used to culminate in the vujári ceremony in which the maternal uncles put their mark on their sister's eldest child by decorating him or her with their clan emblems, at the same time sanctioning his/her right to decoration, and consolidating their lifelong allegiance to their uncles' clan. ${ }^{6}$ One such exchange involved the gift of a pig, raised by the initiate's mother and father, to the mother's brothers, who will reciprocate by giving the child an heirloom such as his or her maternal grandfather's pigs' tusks. The trussed pig is laid on a pandanus mat and covered with a piece of tapa (Figure 30). After the pig has been slaughtered and butchered for distribution among the uncles' clan, the grandmother washes any blood that may have spilt on the mats and tapa and uses them herself.

6 This ceremony, like many others, is harder to organise, and most people opt for a muted version of vujári, or birthday party, in which the maternal uncles give the initiate new clothes and a mirror; string bags are still exchanged in these occasions. 
Both these items are associated with women. They are produced by the initiate's mother and given to the grandmother for having borne the weight of the baby's mother. At a subsequent stage, once the child has been decorated by his mother's brothers with their clan emblems, the child is accompanied out of the house. He or she steps over the maternal grandmother's back before walking on a row of mats to reach the gháito prepared at the centre of the village clearing, where the final and exuberant exchange of gifts between the maternal and paternal clans takes place. The initiate's mother gives mats and other gifts to her brothers and their helpers, and she receives gifts in return from the mother's brothers' wives and from her mother's sisters. The initiate's maternal grandmother is given string bags and taro; this time for bearing the initiate's own weight. While string bags, like the mat, are produced by women, the taro and pig are the product of the joint work of the child's mother and father.

Mats are also part of the exchanges occurring at marriage. When a wife goes to live in her husband's village, women from her own village, her mothers and sisters, will give her several mats to take with her to use in her married life. In turn, these women will receive part of the gift made some time later by the bridegroom to the bride's brothers. Although the groom's return gift is referred to as a gift for the bride's brothers, in fact part of it is shared out to the women of the bride's group of origin, in recognition of their contribution of items made by them. There is a distinction perhaps to be made between the performative moment of the gift giving-when a pile of goods is placed in the centre of the village (a gift from one group to another) — and the redistribution within the group-when individual women, who had given a mat to the bride to take with her, will claim and be given a share of this collective gift.

\section{Conclusions}

Both string bags and mats are first of all ordinary objects, used and valued by women in the course of everyday work. But they enter into social contexts when women choose to give them informally to friends and family, or more ceremonially as part of their brothers' or husband's clan gifts to another clan, thus forging or reinforcing social ties. They are also involved in ritual life, in different ways contributing to the work of transforming and publicly acknowledging the changed status of the protagonists of the ritual. Different domains of life are connected by 
the shared material qualities of these two objects that 'play a determinant role in the non-verbal expression of the principles and values that underlie social relations' (Lemmonier 2013: 136, my translation).

Considering the various life histories of these mundane objects, different kinds of observations can be made. From the point of view of everyday life, string bags and pandanus mats have been with Korafe for a long time. Their value at a prosaic level is the use they are made of by their makers' family members. My interest in these two items lies in the fact that they are used daily by all women and men throughout their lives, they are not just taken out of storage for ceremonial occasions. This does not imply a greater adherence to 'traditional' appearance or aesthetics. Indeed, there is a difference between the two objects in this respect: mats are more 'traditional' in appearance than string bags in which foreign materials designs and techniques are incorporated to a greater extent. However, this difference does not detract from notions of authenticity.

I have selected these two items because of their ordinariness; they are part of every Korafe woman's accoutrement of goods. The skills involved in their manufacture are within the normal repertoire pertaining to adult women. In their very ordinariness lies their relevance for the identity of the women who make, use and give them. It is nonetheless interesting that these same artefacts figure in ceremonial occasions as ritual devices, and also as items of exchange. The values expressed in each context varies; however, the question remains as to the appropriateness of defining them as women's wealth.

In summary, the material value of string bags and mats is embedded in everyday village life, as expressed by their omnipresence. Further, from their involvement in exchanges one may derive a tangible value that is inevitably linked to the immaterial, social significance inherent in the relationships negotiated by the transactions. Both string bags and mats are therefore good examples of artefacts that stimulate us 'to think together about domains that are usually analysed apart' (Coupaye 2013: 251, italics in original). The cultural values expressed by the material nature of these objects are inextricably linked to the women's world at different levels. In the case of mats, the first is the process of transformation of bush material into an artefact that defines domestic space. The second is the movement of the same artefact from the domestic realm into that of social and economic relations, through its introduction into the exchange system. The third is the use of, again the same artefact, to create a safe 
ritual space for the protagonists of ceremony. In all these contexts, these things may be seen to act on people (see also Gell 1998): on the women who make and use them by determining activities, postures and gestures that are typically and exclusively feminine; on those who receive them as gifts and thus become enmeshed in relations of reciprocity; but also on those who use them to restrict their freedom of movement, which, at the same time, allays their fears in situations of vulnerability.

Though these two items may act on people, it is only through the will, knowledge and actions of women who make and use them that they do so. In response to Lissant Bolton's (2001: 266) suggestion that the agency of things should be analysed in terms of the relationships in which they operate, Eves' argues that 'what things do is often not so inseparable from what things are or what is done to or with them' (2009: 260). Further, according to Coupaye, the properties of an object originate from the materials and actions constituting its productive process considered within its social context, the maker's status and the social value attached to her work, and 'simultaneously her/his network of reasons and intentionalities permeates, surrounds and informs the actual artefact $s /$ he produced' (2013: 92).

It is therefore clear that string bags and mats are strongly associated with women's gender identity. They embody the values of women's work and express their intentionality and agency. The value attributed to these two ordinary artefacts is conveyed by two Korafe idiomatic terms for 'wealth': guguá, which literally translates as 'roll of pandanus mats' referring to possessions assembled to take on a trading voyage; and áti ghayáfa, or those string bags filled with other valuables and given in exchange feasts- the same term is now used to refer to a commercial bank, where one's wealth in money is deposited (Farr et al. 2008: 731). Obviously they are valuable items, part of the family's possessions, avowedly produced and managed by women both in daily life and in exchanges. Nonetheless, I am reluctant to draw the conclusion that this makes them women's wealth. Though women may gain in reputation for the quality or quantity of items given, and demonstrate considerable agency and autonomy in making and giving mats and string bags, this is not translatable into a separate realm in which women compete among themselves for power and prestige through gift exchange. 
Bolton (2003: 123-24) shows that textiles embody women's commitment to the social relationships in which they are enmeshed, an investment in relationships that does not start and end with the exchange, but is born in the making of the objects. Similar observations were made by MacKenzie concerning string bags (1991: 142, 150-52). It is at this point, I contend, that women's relative autonomy and intentionality become relevant to our understanding of the significance of material objects in both informal and formal exchanges. When women give string bags or mats informally, they do so to affirm and strengthen personal ties, calling attention to their feelings and sentiment of caring for the recipient, be it a husband, son, brother, father or a sister.

When they give mats or string bags in ceremonial exchanges, women, it is true, do so as a contribution to a patrilineal clan's overall gift. By materially supporting the efforts of the clan, women actively and publicly affirm their affiliation to that patrilineal clan as sisters or wives, although not in all cases is this an either/or choice. Women can, independently of their husbands, decide to contribute to their brothers' clan gifts to a third clan. The different relationship of sisters and wives to the patrilineal clan is reflected by the more public and performative style of the wives' gifts, while sisters express caring for their clan of origin by bringing mats or string bags that their brothers' wives add to their piles of gifts. However, the point remains that women intentionally choose to contribute the things they have made to either patrilineal clan, that of their brothers and/or that of their husband. And that intentionality is fielded, as Bolton suggested, at the moment when they begin to collect the raw material for making the mats or string bags.

Annette Weiner's suggestion (1976: 126, 199) that we should consider brother-sister relations and sibling intimacy as critical and Maurice Godelier's (1999: 33-34) observation of the status of women in patrilineal clans relative to their husbands and brothers are both relevant when exploring questions of women's valuables and their roles in exchange. ${ }^{7}$ In all cases, women see their contribution to clan exchanges as part of their work of caring for their kin and clan, this being one of the core values in the gendered identity of Korafe women. At the same time, the

7 Though this argument goes beyond the scope of this paper, it is my hunch that the different articulations of brother-sister relations in matrilineal and patrilineal societies may explain why women's wealth of the kind described in the Tobriands cannot be so easily found in patrilineal societies like that of the Korafe. 
individual maker's contribution is recognised in the distribution of return gifts, and her work is not totally subsumed within the patrilineal clan, to whose prestige women choose to contribute with more or less work on each single occasion.

\section{Acknowledgements}

I wish to thank John Barker, Adine Gavazzi, Anna-Karina Hermkens, Kathy Lepani and Anna Paini for commenting on earlier versions of this text.

\section{References}

Appadurai, Arjun (ed.). 1986. The Social Life of Things: Commodities in Cultural Perspective. Cambridge: Cambridge University Press.

Barker, John. 2008. Ancestral Lines: The Maisin of Papua New Guinea and the Fate of the Rainforest. Toronto: University of Toronto Press.

Bolton, Lissant. 2001. 'Classifying the Material: Food Textiles and Status in North Vanuatu'. Journal of Material Culture 6(3): 251-268. DOI: $10.1177 / 135918350100600301$.

—_. 2003. Unfolding the Moon: Enacting Women's Kastom in Vanuatu. Honolulu: University of Hawai'i Press.

Coupaye, Ludovic. 2013. Growing Artefacts, Displaying Relationships: Yams, Art and Artefacts amongst the Nyamicum Abelam of Papua New Guinea. New York and Oxford: Berghahn Books.

Eves, Richard. 2009. 'Material Culture and the Magical Power of Dance Objects'. Oceania 79(3): 250-262. DOI: 10.1002/j.1834-4461.2009. tb00063.x.

Farr, James and Cynthia Farr, with Korafe and Yegha speakers. 2008. Korafe-Yegha da Dikiseneri / The Korafe-Yegha Dictionary. Online: www-01.sil.org/pacific/png/pubs/928474533810/Korafe_Dictionary_ Updated\%20version.pdf (accessed 24 April 2017).

Gell, Alfred. 1998. Art and Agency: An Anthropological Theory. Oxford: Clarendon Press. 
Gnecchi-Ruscone, Elisabetta. 1992. 'Power or Paradise? Korafe Christianity and Korafe Magic'. PhD thesis. Canberra: The Australian National University.

- 2007. 'Parallel Journeys in Korafe Women's Laments (Oro Province, Papua New Guinea)’. Journal de la Société des Océanistes 124: 21-32.

Gnecchi-Ruscone, Elisabetta and Jan Hasselberg. 2012. 'Ad-dressing and De-vesting the Bodies: Changing Practices in Body Adornment, Coastal Oro Province, Papua New Guinea'. Paper presented at the 9th European Society for Oceanists Conference, Bergen.

Godelier, Maurice. 1999 [1996]. The Enigma of the Gift. Chicago: University of Chicago Press. Trans. from French by Nora Scott. 1996. L'Enigme du don. Paris: Libraire Arthéme Fayard.

Hermkens, Anna-Karina. 2013. Engendering Objects: Dynamics of Barkcloth and Gender among the Maisin of Papua New Guinea. Leiden: Sidestone Press.

Ingold, Tim. 2013. Making: Anthropology, Archaeology, Art and Architecture. Oxon and New York: Routledge.

Lemmonier, Pierre. 2012. Mundane Objects. Materiality and Non-verbal Communication. Walnut Creek, CA: Left Coast Press.

— 2013. 'De l'immatériel dans le matériel... et réciproquement! Techniques et communication non verbale'. Le Journal de la Société des Océanistes 136-137: 15-26.

MacKenzie, Maureen. 1991. Androgynous Objects: String Bags and Gender in Central New Guinea. Chur and Melbourne: Harwood Academic Press.

Strathern, Marilyn. 1988. The Gender of the Gift: Problems with Women and Problems with Society in Melanesia. Berkeley: University of California Press.

Weiner, Annette. 1976. Women of Value, Men of Renown: New Perspectives in Trobriand Exchange. Austin, TX: University of Texas Press.

- 1992. Inalienable Possessions: The Paradox of Keeping-While-Giving. Berkeley: University of California Press. 
Were, Graeme. 2013. 'On the Materials of Mats: Thinking through Design in a Melanesian Society'. Journal of the Royal Anthropological Institute 19(3): 581-599. DOI: 10.1111/1467-9655.12051.

Young Leslie, Heather E. 2007. '...Like a Mat Being Woven'. In Hybrid Textiles: Pragmatic Creativity and Authentic Innovations in Pacific Cloth, ed. Heather Young Leslie, Ping-Ann Addo and Phyllis Herda. Special issue of Journal of Pacific Arts 3(5): 115-127.

Young Leslie, Heather, Ping-Ann Addo and Phyllis Herda (eds). 2007. Hybrid Textiles: Pragmatic Creativity and Authentic Innovations in Pacific Cloth. Special issue of Journal of Pacific Arts 3(5). 
This text is taken from Sinuous Objects: Revaluing Women's Wealth in the Contemporary Pacific, edited by Anna-Karina Hermkens and Katherine Lepani, published 2017 by ANU Press, The Australian National University, Canberra, Australia.

dx.doi.org/10.22459/SO.08.2017.05 